tain chain. To every observer, indeed, this must be obvious, Two reasons have been adduced in explanation- $\mathrm{I}$. That the glaciers have been smaller from the cold of the glacial period not having extended over Italy, as indicated by the absence of the reindeer and other sub-arctic species from the drift ; 2 . That denudation has been enormous. In spite of the southern exposure it hardly appears probable that there could have been sufficient difference in the size of the northern and southern glaciers to cause this contrast, as long as the glacial period lasted, for the vapour-laden winds from the sea must have deposited much of their moisture on the southern slopes as nnow. But, as the ice-age passed away, the southern aspect of the Alps would doubtless be freed from its influence sooner than the northern, and bence, while snow and ice reigned in the latter area, the regions south of the mountains underwent denudation, probably, for a vast period. I would therefore suggest that the comparatively small amount of glacial débris on the southern side of the Alps may arise from that region having been exposed for a much longer time to sub-aërial waste, and in particular to the floods caused by the more rapid melting of the snows on the southern slopes of the mountains.

so, Old Square, Birmingham, December I6

\section{Electric Lighting}

IN the Procecdings of the Philosophical Society of Manchester $\mathrm{Mr}$. Wilde has described a new electric lamp, in which the carbons are placed parallel to each other, as in a Jablochlioff candle, but without any insulating material. It may not be apparent to all why the arc always locates itself at the extremity of the pair of carbons, and this, as Mr. Wilde observes, whether the lamp be erect or inverted. The explanation is that the current in each carbon repels the electric arc exactly as the current in the mercury-troughs repels the connecting cross-wire in a well-known experiment of Ampère. In Wilde's candle we have two fixed conductors, the carbons, and a movable conductor, the arc. Since the current in the arc and the current in either carbon are one from the other towards the point of junction of that carbon with the arc, the arc must be repelled by the carbon. One cannot but be surprised that Ampère's experiment did not suggest the discovery made by Mr. Wilde, that the insulating material might with advantage be omitted in Jablochkoff 's candle.

4, Westminster Chambers, December I 2

\section{The Reproduction of the Eel}

THE time of spawning and the differences between the sexes of the common eel has been hitherto unknowis. Last year for the first time in this country eels (Anguilla bustoniensis) containing eggs were found, December 31, by Mr. Edwards, at New Bedford, Mass, as stated by Mr. Putnam in the Proceedings of the Boston Society of Natural History. From observations on eels brought me at Providence, R.I. it appears that eels spawn here in salt or brackish water from October to the end of November, as I have found several eels containing eggs which seemed nearly ripe, the ovary being full and large. To-day on examining the testis of a male cel 17 inches long, the mothercells and sperm-cells were found, the latter numerous and lively, from $\frac{1}{3000}$ to $\frac{1}{20000}$ inch in diameter. The eggs were white, just large enough to be distinguished by the naked eye, measuring a little less than $\frac{1}{2} \mathrm{~mm}$. in diameter. The females are larger than the males, with the belly white, while the males are easily distinguishable by the dark bellies and a narrow silvery or golden median stripe.

Laboratory of Brown University, U.S., November 27

\section{AERATED BREAD}

SOME remarks upon aerated bread which were made by Dr. B. W. Richardson at the recent general meeting of the company working Dr. Dauglish's patents require examination. Now it is noteworthy how imperfect our knowledge of the chemistry of the millproducts from the cereal grains still remains. Without such knowledge we are not in a position to dogmatise as to the exact nutritive values of different kinds of bread. As I pointed out in a previous article on "Real Brown
Bread," the statement that whole wheaten meal, bran, pollard, \&c., contain more nitrogen, and therefore more flesh-formers than fine flour, rests upon no certain basis of analytical fact. And if it were proved that all the nitrogen of the most nitrogenous of mill-products does really exist in what are called albuminoids or fleshformers, we cannot ignore the presence of much indigestible fibrous material in bran and pollard, material which is not only non-nutritive itself, but which locks up in an inaccessible form much of the real nutrient substances associated with it. Thus a sample of wheaten bran, or rather, fine pollard, may refuse to give up to the boiling dilute acid and alkali used in fibre-determinations more than six-sevenths of its nitrogenous matter; and it can hardly be expected that the secretions of the alimentary canal will prove successful in withdrawing a larger proportion. Indeed, the analysis of the residues of such foods after having been submitted to the digestive process, has confirmed this expectation in the case of the human subject. Moreover, while a not inconsiderable part of the albuminoid matters of the outer coverings of the grain thus escapes digestion from its mechanical condition, there is good reason to believe that a further portion remains unabsorbed, by reason of the rather hurried passage of the branny particles through the digestive tract. And the same causes which operate to prevent a part of such flesh-formers as exist in the bran from being utilised, affect also and in a similar way the useful mineral substances which abound in the coarser mill-products, as well as the oil or fat which they contain.

Now let us see what are the distinctive advantages claimed for Dr. Dauglish's bread-making process by Dr. Richardson. It yields a bread which is said to be "perfectly clean, perfectly wholesome, and completely nutritious." As to the perfect cleanliness of this mechanical process for making bread there can be no question; it is immeasurably superior to the barbarous and old, but, as Dr. Richardson remarked, not "time-honoured system of kneading dough by the hands and feet of the workman." And we may agree, with almost equal confidence, in the statement that aerated bread is perfectly wholesome. The stream of pure water charged with carbonic acid gas vesiculates the dough, which has required neither alum, nor blue vitriol, nor lime-water, to check the irregular fermentation, and neutralise the sourness of nouldy or otherwise damaged or inferior flour. But, on the other hand, the adoption of the aerating process does not of itself necessarily exclude all adulterations of the bread: materials to whiten the loaf and to cause the retention of a larger percentage of water may still be used. As to the small loss of nutrient materials involved in the ordinary fermentation of dough, it hardly merits consideration. Perhaps Dr. Richardson alluded to it because it gave him an opportunity of having a fling at his old enemy, alcohol, of which it has been found that a newly-baked loaf, made by means of yeast, contains about 0.25 per cent. So that a man who eats twenty quartern loaves has therein consumed an amount of alcohol which is commonly contained in one bottle of port! But if there be no really serious loss of starch by conversion, first into sugar, and then into carbonic acid gas and alcohol, there can be no doubt that a number of altered products are present in a fermented loaf, and that these are less abundant and less variable in nature in aerated bread. But the presence in fermented bread of larger quantities of sugar, gum, and soluble starch than are found in aerated bread is not usually a disadvantage so far as the digestibility of the loaf is concerned. It is rather to the production of lactic acid and of nitrogenous ferments by the use of yeast or leaven that we should attribute the uncertain value of ordinary bread. The quality of the yeast, too, must not be left out of consideration, as some of our home and of our imported. supplies are by no means of a satisfactory character.

$$
{ }^{\prime} \text { See Natuke, vol. xviij, p } 229 .
$$

